Сделан вывод, что в современных условиях переформатирования полиции в Украине принцип «сommunity policing» становится определяющим.

Ключевые слова: полиция, принципы, деятельность полиции, зарубежный опыт, Украина.

Ievtushok V., Tsebynoga V. Principles of Police Activity: Foreign Experience and Prospects of their Implementation in Ukraine

This paper identifies the relevance of this study, which is due to the borrowing of European experience in reforming the police and the definition of the basic principles of its activities. The authors emphasize that the current legislation of Ukraine defines a number of principles, among them: the principle of the rule of law, the rule of law, respect for the rights and freedoms of citizens, political neutrality, openness and transparency, interaction with the population on the basis of partnership and continuity.

In this article it is determined that in Georgia the basic principle of police activity is the principle of interaction with the public, where the police is focused on civil society. It is noted that in Georgia, policing measures taken by police officers should proceed from the content of the rule of law principle, preventive measures and measures for responding to offenses must comply with the requirements of the law. According to the principle of reservation in relation to the law, the use of police measures restricting human rights and freedoms, recognized by the Constitution of Georgia, is permitted only on the basis of law.

It is concluded that under the modern conditions of reforming the police in Ukraine, the principle of "community policing" becomes decisive. It has been determined that the foreign experience of defining the principles of police activity indicates the transition to a new format of police activity, where the main principle is recognized as «community policing»- community-based police, that is, society. Thus, we can conclude that today, in Ukraine, in the context of reformatting the nature of the police to the body that provides services to the population, it should be noted that the principle of interaction between the police and the population becomes decisive. But at the same time, within one article it is impossible to examine all elements of the positive experience of the police, which determines the prospect of further study of this topic.

Key words: police, principles, police activities, foreign experience, Ukraine. галузевого права та правоохоронної діяльності Центрального украйнського державного педагогічного університету імені

В. Винниченка (м. Кропивницький, Україна)

\title{
ПРОБЛЕМНІ ПИТАННЯ ВЗАЄМОДІЇ ЦЕНТРАЛЬНИХ ОРГАНІВ $З$ РЕГІОНАЛЬНИМИ ОРГАНАМИ ВИКОНАВЧОЇ ВЛАДИ ТА ПОРІВНЯЛЬНИЙ АНАЛІЗ ІЗ ЗАРУБІЖНИМИ КРАЇНАМИ
}

У статті проведено аналіз проблемних питань взаємодії центральних органів з регіональними органами виконавчої влади України та порівняльний аналіз із зарубіжними країнами. Висвітлено пріоритетні напрями вдосконалення організації та діяльності органів виконавчої влади в Україні 3 
огляду на основні зарубіжні принципи та стандарти, сформовані провідними регіональними організаціями.

Ключові слова: адміністративна реформа, державне управління, публічна адміністрація, система органів виконавчої влади, територіальні органи виконавчої влади, центральний орган виконавчої влади.

Постановка проблеми. Реформування системи державного управління та органів виконавчої влади в Україні передбачає передусім «створення сучасної, конкурентоспроможної держави, визначальними характеристиками якої $\epsilon$ верховенство права й розвинена правова культура, збалансована представницька демократія, сильне самоврядування, дисциплінований i мобільний менеджмент».

Становлення незалежної Української держави відбувається досить болісно для нашого суспільства, адже багато громадян доведені до стану зубожіння, i, як наслідок - зневірилися в кращому майбутньому. Однією 3 причин такого є недосконала система організації виконавчої влади. Зокрема, це проявляється в неможливості проведення системних реформ через відсутність генеруючого центру таких реформ, роль якого в більшості країн відіграє уряд, та ефективної виконавчої вертикалі, яка мала б послідовно втілювати їх у життя.

Саме для зміни ідеології держави та побудови ефективної виконавчої влади є необхідним проведення повноцінної реформи в Україні. Адже ще 20 вересня 1995 року постійна Комісія Верховної Ради України 3 питань правової політики і судово-правової реформи ухвалила рішення про створення робочої групи для підготовки Концепції адміністративної реформи [2, с. 8-9]. Під адміністративною реформою розуміють комплекс політико-правових заходів, які полягають у структурних, функціональних та державно-службових змінах передусім у сфері виконавчої влади для перетворення iï 3 владно-репресивного механізму на організацію, що служить суспільству, і створення на цій основі ефективної системи державного управління. Без реформи в органах виконавчої влади неможливе системне й послідовне проведення інших реформ у державі, насамперед економічних і соціальних [3, с. 4].

Аналіз останніх досліджень і публікацій. Зазначимо, що окремі питання реалізації реформи в органах виконавчої влади в Україні були предметом дослідження таких вітчизняних учених, як В. Авер'янов, О. Андрійко, О. Бандурка, В. Білоус, Ю. Битяк, І. Голосніченко, Н. Гутарева, С. Додін, В. Кампо, Р. Калюжний, В. Колпаков, А. Комзюк, В. Копєйчиков, В. Кравченко, С. Курінний, В. Марчук, С. Пєтков, О. Петришин, М. Пухтинський, О. Рябченко, В. Цвєтков, В. Шамрай, В. Шаповал та багатьох інших.

Проте грунтовний аналіз наявних робіт із досліджуваної проблеми засвідчив, що вони мають фрагментарний характер, що зумовлює актуальність обраної теми.

Формування цілей. Мета статті полягає в аналізі особливостей проведення реформи в органах виконавчої влади в зарубіжних країнах та 
висвітленні пріоритетних напрямів удосконалення організації та діяльності органів державного управління в Україні.

Виклад основного матеріалу. Доцільно перед аналізом проблеми реформування органів виконавчої влади в Україні та ії територіальних підрозділів безпосередньо звернути увагу на зарубіжний досвід 3 цього питання.

Зауважимо, що в зарубіжних державах деякі міністерства, окрім центрального, мають регіональний апарат і офіси на місцях. Територіальні (периферійні) служби міністерства можуть здійснювати свою діяльність як в межах певних округів національної території, так і за кордоном [1, с. 53].

Скажімо, у США за виконання федеральних законів на місцях відповідають регіональні підрозділи департаментів, які в американській науковій літературі отримали назву «польові» підрозділи. Ці органи департаментів, хоча структурно й не пов'язані 3 органами штатів, усе ж здійснюють свою діяльність у тісному співробітництві з ними. Регіональні підрозділи департаментів також контролюють використання штатами федеральних субсидій [1, с. 53].

У Японії міністерство може створювати свої відділення на периферії. Наприклад, у межах Міністерства охорони здоров'я, праці та добробуту створені декілька місцевих лікарських відділень і резиденцій аптечних наглядачів. У кожній із префектур діють його філіали - відділення стандартів праці, яким, своєю чергою, підпорядковуються пункти нагляду за стандартами праці [1, с. 421].

Складовими елементами системи місцевих органів державної адміністрації у Франції виступають державні периферійні служби, тобто «зовнішні» (периферійні) служби різних міністерств. Саме перед ними поставлено завдання проведення на місцях політики, яку визначає центральний апарат управління міністерства, - підтримання контактів 3 населенням. Ці периферійні служби міністерств приймають повсякденні рішення у відповідних сферах державного управління [1, с. 232].

Периферійні служби залишаються в підпорядкуванні свого міністерства, але водночас вони підпорядковані керівникові департаменту - префекту. Щоправда, окремим периферійним службам вдалось уникнути подвійного підпорядкування й залишитися формально незалежними від префекта (це, зокрема, територіальні служби міністерства оборони, міністерства юстиції, міністерства освіти, служби Інспекції праці та Національного інституту статистики й економічних досліджень). Виведення 3 підпорядкування префекта територіальних служб міністерства оборони зумовлене тим, що їх створюють на базі військових округів, які за своїми розмірами значно переважають територію департаменту або регіону. Що ж стосується територіальних служб міністерства юстиції, які діють у межах Касаційного суду, то вони виведені 3 підпорядкування префекта з огляду на дотримання принципу розподілу влад. Також існують різні територіальні служби міністерства економіки, фінансів і промисловості - податкові служби, генеральне казначейство, служба державного майна, регіональне митне управління. Вилучення 
цих служб з підпорядкування префекта зумовлене особливим впливом, яким міністерство користується в уряді [1, с. 233].

У більшості західних країн основні сфери управлінської діяльності розглядаються як спільні для центральних і місцевих влад, а розподіл компетенції здійснюється або за повноваженням, або за об'єктами регулювання. Скажімо, у Франції у сфері освіти діють і центральні органи, i територіальні колективи. Управління установами початкової освіти здійснюють комуни, коледжами - департаменти, а ліцеями - регіони. Центральна адміністрація відповідає за педагогічне забезпечення навчального процесу та вчительські кадри [1, с. 82-83].

Важливою організаційно-структурною особливістю міністерств є наявність у їх підпорядкуванні місцевих органів, що створюють спільно 3 апаратом міністерств так звану «виконавчу вертикаль» галузевої чи функціональної спрямованості (систему міністерства). Здебільшого на місцевому рівні органами міністерств є управління, відділи та інші структурні підрозділи місцевих державних адміністрацій, які підзвітні та підконтрольні відповідним міністерствам. Саме міністерства забезпечують в установленому порядку координацію діяльності створених ними місцевих органів $з$ місцевими державними адміністраціями.

В Україні, з юридичного погляду, видається недосить врегульованим статус територіальних органів центральних органів влади (далі - ЦОВВ). Адже відповідно до ст. 118 Конституції України «виконавчу владу в областях і районах здійснюють місцеві державні адміністрації», а про органи виконавчої влади, що діють на місцях, не згадується взагалі [6].

Реформування Кабінету Міністрів України має проводитися паралельно 3 реформуванням системи ЦОВВ, які здійснюють свої повноваження на всій території України як безпосередньо, так і через утворені ними територіальні (регіональні) підрозділи (органи) [7].

3 питань здійснення повноважень місцевих державних адміністрацій керівники територіальних органів міністерств та інших центральних органів виконавчої влади підзвітні й підконтрольні головам відповідних місцевих державних адміністрацій. Водночас голови місцевих державних адміністрацій координують діяльність територіальних органів міністерств та інших центральних органів виконавчої влади, сприяючи їм у виконанні покладених на ці органи завдань. Зокрема, право голови місцевої державної адміністрації порушувати перед міністерствами, іншими центральними органами виконавчої влади вмотивовані питання про відповідність займаній посаді керівників їх територіальних органів, на підставі чого міністерство, інший центральний орган виконавчої влади має прийняти рішення та дати обгрунтовану відповідь [122].

Важливим питанням реформування місцевих органів та центральних органів виконавчої влади є забезпечення чітких субординаційних зв'язків між цими органами. Невід'ємною особливістю правового статусу місцевих державних адміністрацій $є$ те, що в ньому певним чином поєднуються повноваження загальної та спеціальної компетенції. Зокрема, повноваження 
спеціальної компетенції здійснюють структурні підрозділи місцевих державних адміністрацій, до повноважень яких належать питання галузевого чи функціонального управління на відповідній території (скажімо, управління охорони здоров'я, фінансове управління тощо).

Голови місцевих адміністрацій, передусім обласних, співпрацюють 3 міністерствами та іншими центральними органами в процесі управління структурними підрозділами цих адміністрацій, що перебувають у сфері управління відповідних центральних органів. Отже, управління, відділи та інші структурні підрозділи місцевих державних адміністрацій підзвітні й підконтрольні відповідним центральним органам виконавчої влади.

У разі визнання центральним органом незадовільною роботу відповідного структурного підрозділу місцевої державної адміністрації або ïx керівників керівник відповідного центрального органу звертається 3 вмотивованим поданням до голови місцевої державної адміністрації, який зобов'язаний розглянути це подання й дати обгрунтовану відповідь або прийняти рішення.

Управління, відділи та інші структурні підрозділи місцевих адміністрацій здійснюють керівництво галузями управління, несуть відповідальність за їх розвиток. По горизонталі вони підпорядковані й підзвітні голові відповідної державної адміністрації, а по вертикалі - органам виконавчої влади вищого рівня - відповідним управлінням, відділам та іншим структурним підрозділам обласної державної адміністрації.

Відносини місцевих державних адміністрацій 3 центральними органами, які мають територіальні органи (підрозділи) в областях і районах, що не входять до складу державних адміністрацій (органи юстиції, внутрішніх справ, служби безпеки тощо), мають менш взаємозалежний характер. Працівники зазначених територіальних органів (підрозділів) підзвітні й підконтрольні головам місцевих державних адміністрацій лише 3 питань здійснення повноважень цих адміністрацій.

Як зазначає В. Кравченко, низка важливих принципів Європейської хартії місцевого самоврядування, попри ії ратифікацію Україною, ще не отримали належного відтворення в чинному законодавстві та суспільній практиці: «Конституція України (ст. 140) передбачає застосування місцевого самоврядування лише на низовому територіальному рівні - рівні населеного пункту (села, селища, міста), на регіональному рівні продовжує існувати система прямого державного управління, що виключає можливість існування регіонального самоврядування. Це певною мірою суперечить принципу, який закріплений у статті 3 Європейської Хартії, і передбачає, що місцеве самоврядування означає «право і спроможність місцевої влади, у межах закону, здійснювати регулювання й управління значною часткою публічних справ...» [10, с. 74].

Безумовно, застосовувати зарубіжний досвід здійснення управлінських інновацій потрібно як з огляду на національні традиції, так і національні інтереси. Але ця умова виконується в тому разі, коли інноваційний досвід використовується на основі добре розробленої концепції реформування вітчизняної системи державного управління, основний компонент якої має 
винятково національний характер. «Якщо технології можна запозичити, узяти з того чи іншого досвіду, то ідеологія державного управління в кожній країні має самостійно формуватися ії інтелектуальними й політичними елітами» $[4$, с. 10$]$.

Висновки. Отже, реформи в різних країнах відбуваються за допомогою різних стратегій, що залежать від часу та особливих умов. Проте існують спільні завдання започаткування й впровадження цих реформ, спрямовані на підвищення ефективності, дієвості та підзвітності управлінських структур, децентралізацію, передання функцій на нижчі рівні управління, зміцнення самоврядування, поліпшення результатів діяльності органів влади.

Для вітчизняного реформування органів виконавчої влади найбільше значення має не лише досвід конкретних напрямів реформ систем державного управління в зарубіжних країнах, а i їх соціокультурне та системно-управлінське обгрунтування. Методологію поєднання еволюційних і радикальних реформ, системне моделювання адміністративних реформ, орієнтацію інноваційних процесів на зростання якості державного управління доцільно використати як концептуальний фундамент трансформації системи державного управління в Україні. Це не лише дасть змогу залучити зарубіжний практичний досвід удосконалення управлінської діяльності, а й забезпечить соціокультурну трансформацію вітчизняної системи управління в євроінтеграційному напрямі. До того ж основним напрямом дальших досліджень має стати саме проблема соціокультурного наповнення концептуальних засад вітчизняної адміністративної реформи в контексті процесів євроінтеграції [13, с. 86- 94].

\section{Використані джерела:}

1. Административное право зарубежных стран / под ред. А. Н. Козырина, М. А. Штатиной. Москва: Спарк, 2003. 464 с.

2. Адміністративна реформа - історія, очікування та перспективи / упоряд. В. П. Тимощук. Київ: Факт, 2002. 100 с.

3. Адміністративна реформа для людини: науково-практичний нарис за заг. редакцією І. Б. Коліушко. Центр політико-правових реформ. Київ. 2001. 72 с.

4. Атаманчук Г. Методологічні проблеми сучасного державного управління. Вісник Української академії державного управління. 2001. № 3. С. 9-12.

5. Коліушко І. Б. Виконавча влада та проблеми адміністративної реформи в Україні. Київ: Факт, 2002. 260 с.

6. Конституція України: Закон України від 28.06.1996 № 254к/96-BP. URL: https:/ / zakon.rada.gov.ua/laws/show/254 к/96-вр (дата звернення: 29.12.2018).

7. Концепція адміністративної реформи в Україні. Київ, 1998. 62 с.

8. Котляр Д. Окремі аспекти проведення адміністративної реформи та організація центральної виконавчої влади в країнах світу. Часопис Парламент. 2000. № 6. C. 24-28.

9. Максименко С. Регіональна політика в країнах Європи:уроки для України. Київ : Логос, 2000. 69 с.

10. Місцеве самоврядування: 10 років здобутків / за заг. ред. М. Пухтинського. Київ : Атіка, 2002. 268 с. 
11. Нижник Н., Лемак В. Адміністративна реформа в країнах Центральної Європи: досвід для України. Вісник державної служби України. 2003. № 2.

12. Про місцеві державні адміністрації: Закон України від 09 квітня 1999 року № 586-XIV. URL: https://zakon.rada.gov.ua/laws/show/586-14 (дата звернення: 27.12.2018).

13. Хачатурян Х. Європейський концептуальний контекст управлінських інновацій в Україні. Актуальні проблеми державного управління: зб. наук. праць / редкол.: С. М. Серьогін. Дніпропетровськ : ДРІДУ НАДУ, 2006. Вип. 1 (23). 292 с.

Стаття надіӥшла до редколегї 15.01.2019

Окопник Е. Н., кандидат юридических наук, доцент, доцент кафедры отраслевого права и правоохранительной деятельности Центрального украинского государственного педагогического университета имени В. Винниченко (г. Крапивнищкий, Украина)

Проблемные вопросы взаимодействия центральных органов с региональными органами исполнительной власти Украины и сравнительный анализ с зарубежными странами

В статье проведен анализ проблемных вопросов взаимодействия центральных органов с региональными органами исполнительной власти Украины и сравнительный анализ с зарубежными странами. Освещены приоритетные направления совершенствования организации и деятельности органов исполнительной власти в Украине с учетом основных зарубежных принципов и стандартов, сформированных ведущими региональными организациями.

Ключевые слова: административная реформа, государственное управление, публичная администрация, система органов исполнительной власти, территориальные органы исполнительной власти, центральный орган исполнительной власти.

Okopnyk O. Problematic Issues of Interaction of Central Bodies with Regional Executive Bodies of Ukraine and the Comparative Analysis with Foreign Countries

The article analyzes problematic issues of interaction of central bodies with regional executive bodies of Ukraine and comparative analysis with foreign countries. The priority directions of improvement of the organization and activity of executive authorities in Ukraine are highlighted taking into account the main foreign principles and standards formed by the leading regional organizations.

The formation of an independent Ukrainian state is quite painful for our society, since many citizens have been brought to poverty, and as a result, they have despaired in the better future. One of the reasons for this state of affairs is the imperfect system of organization of executive power. This is manifested, on the one hand, in the impossibility of systematic reforms due to the lack of a generating center for such reforms, the role of which in most countries is played by the government, and an effective executive vertical that should consistently implement them.

In most Western countries, the main areas of management activity are considered as common to central and local authorities, and the division of competencies is either exercised or regulated. An important organizational and structural feature of the ministries is the presence in their subordination of local authorities, which together with the apparatus of ministries create the so-called "executive vertical" of the sectoral or functional orientation (the system of the ministry). 
Of course, the application of foreign experience in the implementation of managerial innovations is necessary taking into account both national traditions and national interests.

Not only the experience of concrete directions of reforms of the systems of public administration in foreign countries, but also their socio-cultural and systemmanagement substantiation is of greatest importance for the domestic reform of the executive authorities. At the same time, the main problem of further research should be the problem of socio-cultural filling of the conceptual foundations of domestic administrative reform in the context of the processes of European integration.

Key words: administrative reform, public administration, public administration, system of executive authorities, territorial executive authorities, central executive authority.

УДК 351.741

Циганов О. Г.

доктор юридичних наук, доцент, головний науковий співробітник НДЛ проблем правового та організаційного забезпечення діяльності Міністерства ДНДІ МВС України (м. Київ, Україна)

\section{ПІДХОДИ ДО З'ЯСУВАННЯ СУТНОСТІ ПОЛІЦЕЙСЬКИХ ПОСЛУГ: ВІТЧИЗНЯНІ РЕАЛІЇ ТА ЗАРУБІЖНА ПРАКТИКА}

У статті досліджено «відсутність зброї» як ознака права на мирні зібрання. Досліджено загальноприйняте лінгвістичне розуміння поняття «зброя», а також нормативно закріплені поняття «зброя» у підзаконних нормативно-правових актах. На підставі аналізу поняття «зброя» та його співставлення з умовами здійснення права на мирні зібрання сформульовано складові елементи такої ознаки права на мирні зібрання, як «відсутність зброї».

Ключові слова: право на мирні зібрання, ознака, зброя, відсутність зброї.

Постановка проблеми. Надання послуг населенню за умов усебічної сервізації сфери публічного адміністрування перетворюється на магістральний напрям діяльності всіх органів державної влади, серед них і правоохоронних. У багатьох країнах світу поряд із традиційними завданнями поліції стратегічним напрямом розвитку цього органу правоохорони стає публічно-сервісний напрям.

Попри те, що на сьогодні в Україні нормативного визначення поняття «поліцейська послуга» не існує, можна стверджувати, що надання таких послуг є важливою складовою поліцейської діяльності. Утім, відсутність законодавчого визначення цього поняття, його властивостей та ознак стає основою для дискусій, відкриваючи необмежені можливості для дальших наукових досліджень. Водночас проведений нами аналіз засвідчив відмінності в розумінні категорії «поліцейська послуга» серед вітчизняних і зарубіжних фахівців у галузі публічного адміністрування.

Аналіз останніх досліджень і публікацій. Науковій розробці проблем поліцейської діяльності та ефективності ї̈ здійснення присвятили свої праці М. І. Ануфрієв, О.М.Бандурка, Ю.П.Битяк, В. М. Білик, В. О. Заросило, 